https://doi.org/10.48009/2_iis_2007_315-320

\title{
USING IT TO IMPROVE CONSUMER/PARTNER RELATIONSHIP MANAGEMENT
}

Małgorzata Dolińska, University of Maria Sklodowska-Curie, m.dolinska@umcs.lublin.pl

\begin{abstract}
The customer relationship management (CRM), as an interconnected whole of strategies, systems, processes and information technologies (IT), represents the innovative marketing opportunity for companies. CRM is an effect of the latest management techniques and computer science; it is closely integrated with Internet and e-trade. This work illustrates basic concepts of the CRM strategy and system in networked companies from a relationship marketing perspective. It presents the application of CRM system modules in companies. The objective of this work is to examine whether Polish companies use CRM system and which modules of it they have implemented. Summary results of questionnaire research on this subject are described in this work.
\end{abstract}

Keywords: consumer/partner relationship, CRM system

\section{INTRODUCTION $^{1}$}

Relationship marketing trends and information technology advances have significantly challenged the marketing of companies, which are currently applying consumer relationship management (CRM) strategy or system. Marketers know must work closely with a variety of marketing partners. In addition to being good at customer relationship management, marketers must also be good at partner relationship management. Major changes are occurring in how marketers partner with others inside and outside the company to jointly bring more value to customers.

The goal of CRM strategy is to create profitable long run relationships with clients through three combined activities: to create, build and care for the client, thus generating value. The CRM, therefore, can be defined as a wide ensemble of processes and technologies to manage the company relationship with potential and consolidated customers, and also commercial partners in the production or marketing, sale and service sector [6].

CRM system is a part of an effective overall customer relationship management strategy. It uses

\footnotetext{
${ }^{1}$ This work is financed by Polish Science and High School Ministry (research project no. 1 H02D 060 30)
}

e-commerce channel and World Wide Web (www pages) as a place where customer can make an order, get some information about products and where personnel of a company can be in contact with customers, collect current information about them and develop knowledge about their needs and expectations. Thanks to e-technology (supporting CRM system) enabling making wide trade structures, company is able to gather information and knowledge from branches about forecasted profits in next periods. Many departments in the company's structure can now use these information and knowledge. This means that manager is able to receive the most recent profit's forecasts, he can analyze it and he can create his own sale's forecast based on incoming data and than pass it to his superiors [8].

The focus of CRM is to improve levels of customer satisfaction, boost customer loyalty, and increase revenues from existing customers in the face of staff competition, globalization, high customer turnover, and growing customer acquisition costs. It then shifts from maximizing a single sale to maximizing a customer's lifetime value to the company [6]. Companies are using customer relationship management to retain current valuable customers or partners and built profitable long-term relationships with them. Nowadays, keeping consumer is very important due to extremely high cost of getting new one. A grater understanding of how CRM creates value can help a business better align its CRM strategy with its overall marketing strategy.

\section{BUILDING RELATIONSHIPS WITH CUSTOMERS AND PARTNERS}

In today's marketplace, competition no longer takes place between individual competitors. Rather, it takes place between the entire value-delivery networks created by these competitors. Marketers must work closely with partners in other company departments to form an effective value chain that serves the customers. They must partner effectively with other companies in the marketing area to form a competitively superior valuedelivery network. Each company department ought to function as a link in the company's value chain.

The introduction of a new information and communication technology generates new company opportunities: innovations, client 
satisfaction and, sometimes, creation of new contacts; and consequentially, new market and further profit sources. The Internet has become a mean of production and marketing that makes firms obtain efficiency and savings in terms of time and money. It is used by enterprises in several ways: from the simple information research on line, to the birth of an higher number of firm websites, to the on-line sale; from the e-mail use to more elaborate applications such as CRM. The Internet has also an extraordinary potential concerning the distribution channel and the supply chain. It eliminates the distances between enterprise and client, it shortens the supply chain and it narrows costs and time to market. Consumers can now buy virtually any product without going to a store - by telephone, mail-order catalogs, kiosks, and online. Direct marketing will play a growing and important role during customer relationship management.

Boulding et al. [3] constructed the scope of CRM as encompassing strategy, management of the dual creation of value, intelligent use of data and technology, acquisition and dissemination of customer knowledge to appropriate stakeholders, development of appropriate (long-term) relationships with specific customer and/or customer groups, and the integration of processes across the many areas of the firm and across the network of firms that collaborate to generate customer value.

The philosophy of CRM is based on [9]:

- relationship orientation;

- customer retention;

- superior customer value created through process management,

- IT as the enabling technology for discovery and management of customer knowledge.

As companies' business strategies become more customer-oriented with the evolution of mass customization and personalized services, IT are used not only to serve end-users of the organization's products and services. Specifically, the use of IT adds a new dimension to relationship marketing, known as CRM [10].

In order to market effectively to the individual customer, companies gather information from both internal and external sources, and use it to provide a unified view (or profile) of the customer for targeted marketing purposes. Therefore, the effective management of information and knowledge is central and critical to the concept of CRM for [7]:

- product tailoring and service innovation, experience and other characteristics, and the development of mass customization,

- providing a single and consolidated view of the customer,

- calculating the value of the customer,

- establishing a strategy for a multi-channel based communication with the customer,

- designing and developing personalized transactions.

CRM involves people: both internal and external customers/partners. The success of customer relationship implementation is highly dependent on the attitudes, commitment and performance of the internal customers. The success in the external customer satisfaction requires success internally in motivating employees and making them committed to the pursuit of the CRM strategy. This area involves the management of customer life cycle and processes relative to knowledge management.

The following rules characterize the CRM strategy application [11]:

1. Use existing relationship to maximize revenue - CRM focuses on establishing stronger relationships with existing customers, retaining "good" customers and weeding out "bad" customers. With CRM, customers lifetime value can be maximized by retaining them at previously impossible retention levels. At the same time, acquisition costs for existing customers are leveled down to almost zero for new sales of complementary or new products that the company sells.

2. Use customer knowledge to consistently deliver excellent service - Effective CRM should surprise customers with how well the company knows them. When knowledge about an individual customer aggregates over time and allows company to deliver personalizes service, it increases switching costs for the customer. This lock-in arises from the customer having to explain his need over again to a prospective seller.

3. Develop repeatable sales processes - CRM facilitates integration of customer knowledge through supporting technology and allows companies to use knowledge of past transactions to effectively sell to both new and existing customers. Effectively integrating knowledge management and CRM means that customers can expect to have consist, dependable, and accurate answers to the CRM facilities usage of accumulated knowledge about the customer for building a more intimate, value-added relationship.

4. Deliver value and develop customer loyalty Loyalty can be stimulated by proactively using collected information to resolve issues before 
they become problems. Further, by showing the customer that the company personnel know him, and offering products and services that already consider his needs, personnel can help establish dependence on the company offerings over time.

The goal of CRM strategy is to build the right relationships with the right customers. Marketers should view customers as assets that need to be managed and maximized, but not all customers, not even all loyal customers, are good investments. Companies want not only to create profitable customers, but to "own" them for life, capture their customer lifetime value, and earn a greater share of their purchases. Beyond offering consistently high value and satisfaction, marketers can use specific marketing tools to develop stronger bonds with customers. They are developing customer loyalty and retention programs. The company can classify customers accordingly to their potential profitability and manage its relationships with them accordingly. Strategy data accumulating and analyzing is also one step forward to optimal offer's planning, marketing actions, and reactions on changing situation on market.

\section{AN APPLICATION OF CRM SYSTEM}

Telecommunications, information, transportation, and other technologies has had a major impact on the ways companies bring value to their customers. The IT boom has created exciting new ways to learn and track customers and to create products and services tailored to individual customer needs. This technology is also helping companies to distribute products more efficiently and effectively. And it's helping them to communicate with customers in large groups or one-to-one [1]. Thanks to IT, today's marketing managers can gain direct access to the information system at any time and from virtually any location. In addition, companies are increasingly allowing key customers and value-network members to access account, product, and other data on demand through extranets.

CRM system is defined as business management and automation of in front-office divisions of an organization. It permits to fit results received in taking and analyzing data about client process to organizational company's abilities [12]. CRM software is essentially meant to address the needs of marketing, sales \& distribution and customer service and support divisions within an organization and allow them to share data on prospects, customers, partners, competitors and employees. It has also organizational functions; it connects database with useful and able to plan trade-marketing actions. The purpose of CRM system is to manage the customer through the entire lifecycle. The implementation of CRM strategy is enabled by technology and CRM system, and requires a customer-centric business philosophy and culture.

CRM system consists of sophisticated software and analytical tools that integrate customer and partner information from all possible sources, analyze it in depth, and apply the results to build stronger customer or partner relationship. A key principle of CRM is to be able to identify each customer individually and link information about that customer across the enterprise. Each contact or interaction represents an opportunity to learn more about the customer's habits, preferences and value to the firm. CRM systems allow managers to get the information or knowledge they need directly and quickly and to tailor it to their own expectations.

CRM system automates many of the needs of marketing, sales and support users, such as telephony, or the ability to conduct phone calls and manage call data, and tools to capture, share and manage automated alerts on lead data as it passes through the sales pipeline. CRM software provides a standard framework for pushing through a sales pipeline and managing it amongst many stakeholders in real time, in order to provide better customer relations and grow revenues by creating more sales, and losing fewer customers. The major challenge is data integration. The basis for obtaining the complete benefits is to get all the front and back-office technologies working together and to ensure that the same customer information is available at all customer touch points in all channels.

The CRM architecture of the innovative, customer-oriented organization is constituted by processes designed around the client/partner, rather than the marketing, the sales or other internal functions [12]. CRM analysts develop data warehouses and use sophisticated data mining techniques to unearth the riches hidden in customer/partner data. A data warehouse is a company wide electronic database of finely detailed customer information and knowledge. The purpose of a data warehouse is not just to gather information, but to pull it together into a central, accessible location. Then, once the data warehouse brings the data together, the company uses highpowered data mining techniques to sift through the mounds of data and dig out interesting findings about customers and/or partners.

CRM system includes the majority of modules mentioned above $[2,5,10]$ :

- relationships management (customers' 
profiles, institutional customers' structure, history of relationships and service);

- sales management, client's account management (the history of sales contacts, making offers, orders, trade transactions, analyses during sale cycle);

- correspondence - mailing, e-mail, fax;

- marketing - campaign management, products' catalogues offers, price lists, analyses of campaign's efficiency; distribution of information about clients who are interested in the offer and the one who are responding in the campaign;

- order processing;

- telemarketing;

- service and support client after a sale - task giving, watching and reporting, service problems management, orders control, guarantee and after guarantee service;

- watching customers' status and looking for a another potential trade contacts;

- schedule and correspondence management diary and data bases of individual user or whole group, service of traditional correspondence and e-mails, faxes;

- telemarketing;

- integration with ERP systems - production, distribution, accounts;

- finance management, accounts, production, distribution, human resources management;

- data synchronization - it means co-operations between mobile equipment and central data base or others data bases and servers;

- e-commerce;

- call centre - service client’s support.

There are three parts of CRM system and each of them can be implemented in isolation from one another $[2,10]$ :

- operational CRM: automation or support of customer processes that include a company's sales or service representative;

- collaborative CRM: direct communication with customers that does not include a company's sales or service representative ("self service");

- analytical CRM: analysis of customer data for a broad range of purposes.

Operational CRM provides support to "front office” business processes, including sales, marketing and service. Each interaction with a customer is generally added to a customer's contact history, and staff can retrieve information on customers from the database as necessary. Collaborative CRM covers the direct interaction with customers. This can include a variety of channels, such as internet, e-mail, automated phone/interactive voice response. It can generally be equated with "self service". The objectives of collaborative CRM can be broad, including cost reduction and service improvements.

Analytical CRM analyzes customer data for a variety of purposes including [9]:

- design and execution of targeted marketing campaigns to optimize marketing effectiveness;

- design and execution of specific customer campaigns, including customer acquisition, cross-selling, up-selling, retention;

- analysis of customer behavior to aid product and service decision making (pricing, new product development, etc.);

- risk assessment and fraud detection, in particular for credit card transactions.

By 2007, U.S. companies have spent $\$ 73,8$ billion on CRM systems from companies such as Siebel Systems, Oracle, Microsoft and SAS [1]

The technology requirements of the CRM system are complex, that is [12]:

- a database to store customer information can be a CRM specific database or an enterprise data warehouse; there are many vendors in this space including IBM, ORACLE, Teradata;

- operational CRM requires customer agent support software such as Siebel Systems;

- collaborative CRM requires customer interaction systems, an interactive website, automated phone systems;

- analytical CRM requires statistical analysis software such as Excel, SAS etc., as well software that manages any specific marketing campaigns such as Teradata Relationship Optimizer, Unica.

Each of these parts of CRM system can be implemented in a very basic manner or in a high and complex installation.

In small firms, the CRM projects are typically narrow in scope and are usually deployed in a modular fashion. For example, a firm might choose to automate its order cycle management initially while leaving more complex applications such as customer analytics for a later date (or not do it at all). Unlike small firms, the need to manage large organizations forces larger firms to attempt more ambitious and comprehensive rollouts of CRM systems. These firms find it a lot easier to push through wholesale changes rather than attempt single steps, one at a time. In this situation, it become very important for the firm to have a tighter link between the CRM strategy and programs and the business's overall marketing strategy [4].

Successful implementation of CRM system depends on a number of factors such as fit between of a firm's CRM strategy and its marketing strategy 
and cooperation among entities and persons involved in implementation.

Marketing research on using CRM system in Polish companies was conducted in 50 firms. Data collection was carried out with help of questionnaire and administrated by phone and online. The questionnaire consisted of closed questions. The research sample was chosen as nonprobability, judgment sample of companies. It consists of 20 industry companies and 30 service firms. They vary in size: 30 percent of them belong to large firms and 70 percent of them are medium-sized ones. Firms participating in the survey represent a wide range of industries as manufacturing, financial services, communications, distribution and sale. All respondent firms support CRM system use but they are not using their CRM tools to their fullest capacity currently. 4 percent of these firms (they are large firms) have implemented this system entirely, 12 percent of them are now doing it, and 30 percent of them intend to do it within the next few years. All respondents reported that employees in their firms view CRM system as useful and they confirm that implementation of CRM system in the firm is longlasting process.

The respondents were presented with a list of seven commonly used modules of CRM system and asked to determine which module their firms had applied successfully. The results indicate that more than 50 percent of the respondent firms use the following modules of CRM system: contacts management with consumers and partners (98 percent of the firms), sale management and analysis (84 percent of them), marketing campaign management (62 percent) and e-commerce (54 percent). These data indicate that, there are fewer firms that use the following modules of CRM system: service after a sale (38 percent of the firms), call center (36 percent). Only small percentage of the firms made limited use of CRM system for marketing research (22 percent). These data indicated the relatively high strategic expectations of the respondents regarding the marketing potential of CRM system. They prove that the respondents were of the view that their organization's dependence on CRM systems became central to their companies drive for customer centricity and his value increase.

The respondents also answered the following question: What was the initial motivation for CRM implementation? A four-point Likert scale (“Strongly”, “Moderately”, “Little”, “Not At All”) was used to help the respondents express the degree to which they agreed with each of the questions. This solution is an indication of the respondents' confidence in their answers. As Table 1 shows the motives most widely acknowledged were that CRM system enable to improve customer or partner collaboration and to increase their satisfaction in time. 82 percent of the respondents agreed strongly with this opinion and 18 percent of them moderately agreed with it. 76 percent of the respondents agreed strongly that maximizing customer/partner satisfaction was the main driver for making CRM system implementation, and 24 percent reported that they were moderately influenced by this. To provide the company with a competitive advantage in the market was the strong motivation factor for 52 percent of the respondents, and the moderately motivation factor for 44 percent, and the little factor for 4 percent. 36 percent of the survey respondents agreed strongly that they had made a CRM implementation to increase the company marketing efficiency, 42 percent of them reported that they were moderately influenced by this, and it was not necessarily the motivation for 20 percent of the respondents. 44 percent agreed strongly or moderately that cost reduction was the main driver for implementing CRM system. The findings reported that the firms express their confidence in the contribution of CRM system to customer/partner collaboration improving and their satisfaction increasing. They also highlight the importance of linking the CRM system implementation in the company to its marketing strategy.

Table 1. Initial motivation for CRM implementation Answers Strongly (\%)

To improve customer/partner collaboration

To increase customer/partner satisfaction 82

To provide the company with a competitive

advantage in the market

To increase the company marketing

efficiency

Cost reduction

Moderately (\%)

Little

18

24

24
44

44

42

16

0
0

Not at all (\%)

The respondents were presented with a list of 6 (commonly cited) the following CRM system objectives: increasing the customer acquisition rates, improving the customer service, increasing

the life value of the customer, greater customer retention, developing new products and services, maintaining/improving the market share. For each, they used the four-point scale, ranging from very 
important to not important, to rate the importance of each in creating value for the company. 3 of the 6 objectives were rated as very important by more than half the respondents. These are, in rank order, increasing customer acquisition rates (68 percent), improving the customer service (62 percent), increasing the life value of the customer (54 percent). Following close behind these objectives was greater customer retention (very important for 44 percent of the respondents), and less important objectives were developing new products and services, maintaining/improving the market share. Such a result may be indicative of the sill early stage of CRM system implementation at most firms. It also confirms that dependence on CRM systems will increase in the firms over the next few years.

\section{CONCLUSIONS}

CRM approaches and applications are key factors for modern companies. CRM is a strategy used to learn more about customers' and partners needs, and their behaviors in order to develop stronger relationships with them. Good customer/partner relationships are at the heart of the company success.

Intangible assets such as relationships with customers, partners and supply channels are defined as relational market-based capital of a company which can provide sustainable competitive advantage and added value for a company, its customers and partners.

As competition levels increase and customer become more sophisticated, thus managers of companies need to focus on the direct effects of CRM systems. These involve communicating with customers or partners and successfully meeting their needs and expectations with the aim of creating long-term relationships. Good customer relationship management can help marketers to increase their share of customer - the share they get of the customer's purchasing in their product categories.

\section{REFERENCES}

1. Armstrong, G., \& Kotler, P. (2007). Marketing: an introduction. USA, Pearson Prentice Hall.

2. Bazarnik, J. (2004). Systemy informacyjne o klientach i ich wykorzystanie, in: ed. Szumilak
J. Handel detaliczny, Kraków, Oficyna Ekonomiczna.

3. Boulding, W., Staelin, R., Ehret, M., \& Johnston, W. J. (2005). A Customer Relationship Management Roadmap: What Is Known, Potential Pitfalls, and Where to Go. Journal of Marketing, 64 (4), 155-166.

4. Bohling T., Bowman D., LaValle S., Mittal V., Narayandas D., Ramani G., \& Varadarajan R. (2006). CRM Implementation: Effectiveness Issues and Insights, Journal of Service Research, Volume 9, No. 2, November 2006, 184-194.

5. Brzozowski, J. (2002). Customer Relationship Management and lifetime value of a customer, in: ed. Piech, K. Changes and Challenges of the Contemporary World. Warsaw, The Knowledge Institute, Warsaw School of Economics.

6. Cataldo, G. (2006) A new way to understand marketing - the customer relationship management, in: ed. Rosa, G., \& Smalec, A. Marketing przyszłości. Szczecin, Szczecin University Publisher.

7. Karakostas B., Kardaras D., \& Papathanassiou E. (2005). The state of CRM adoption by the financial services in the UK: an empirical investigation, Information \& Management 42 (2005), pp. 853-863.

8. Koszykowska, K., \& Sebastjanczyk, S. (2002). Customer Relationship Management, in: ed. K. Piech, K. Changes and Challenges of the Contemporary World. Warsaw, The Knowledge Institute, Warsaw School of Economics.

9. Ryals, L., \& Knox, S. (2001). Crossfunctional issues in the implementation of relationship marketing through customer relationship management, European Management Journal, 19(5), 534-542.

10. Teo, T. S. H., Devadoss, P., \& Pan, S. L. (2006). Towards a holistic perspective of customer relationship management (CRM) implementation: A case study of the Housing and Development Board, Singapore. Decision Support Systems, 42 (2006), 1613-1627.

11. Tiwana, A. (2001). The Essentials guide to knowledge management: e-business and CRM applications. New Jersey, Prentice Hall, Upper Saddle River.

12. Aspects of CRM. (2007-02-04). http:// en.wikipedia.org/wiki/Customer_Relationship _Management, 1-4. 